\title{
On Not Throwing Out the Baby: Planning the Future of Legal Information
}

\author{
Robert Berring $\dagger$
}

Legal information is undergoing a radical transformation. New information systems and formats appear regularly, and multinational conglomerates are becoming key players in the marketplace. In the midst of these developments, individuals and interest groups advocate fundamental changes to the way legal information is currently distributed and cited. One proposal, predicated on the notion that the law is a public good, is that the government should compile and distribute legal information to the public at low cost. According to this rationale, the government should replace private publishers as the primary distributor of legal information. Other commentators suggest modifying the citation system currently used to identify cases. At present, many courts require citation to a particular set of printed cases. Critics argue that this system gives official reporters and the West Publishing Company an unfair advantage over competitors. In response, some commentators propose a system of citation that does not refer to the products of specific vendors. This Essay argues that radical reformation is premature and would interfere with the normal operation of the market for legal information. The author suggests that, despite its limitations, the market rewards innovation, accuracy, and cost-effectiveness. As a result, the current system enables low-tech users to find information cheaply and quickly. The author suggests that attempts to prematurely dismantle the existing infrastructure should not be taken lightly; the public has a strong interest in reliable and accessible legal information. The Essay

Copyright $\odot 1995$ California Law Review, Inc.

$\dagger$ Professor of Law and Law Librarian, Boalt Hall Law School, University of California at Berkeley. In the interest of fairness I should point out that over the past two years I have done consulting work for West, LEXIS, Shepard's, Barclays, and Thomson. While this has given me perspective on legal information, all views expressed in this essay are my own.

A dratt of this essay was posted at an FTP site on the Internet, courtesy of the Northern California Association of Law Libraries. Comments were invited. I have thus benefitted from the comments of many of the more than 100 folks who read it in draft. John Lederer, who has worked on the Wisconsin citation project, was especially helpful, though he completely disagrees witl most of what I say. Mark Estes of Holme, Roberts \& Owen in Denver, Colorado and Chris Wren of Wisconsin were also generous. Professor Lynn Foster of the University of Arkansas tried unsuccessfully to make me see the light. 
concludes that market forces, rather than governmental fiat, should dictate changes in the legal information system.

\section{INTRODUCTION}

The landscape of legal information is going to be remade in the inid1990s. The next few years will see consumers, publishers, and the governinent inaking transformative decisions about the legal information we use and how we use it. These decisions will guide development of legal inforination for a generation. ${ }^{1}$

One need not look far to find evidence that the world of legal information is changing. First, where legal research was once a stable, if shifting, universe, today new information systems and formats are flooding bar journals and legal newspapers with their advertisements. ${ }^{2}$ Nor is news about legal information restricted to advertiseinents. In recent inonths, a series of developments concerning legal information has occupied the news pages of papers like the Wall Street Journal ${ }^{3}$ and has even been included as the subject of a seginent on National Public Radio's "Morning Edition."4

Second, there are major new players in the world of legal information. Two multinational information congloinerates have assuined major inarket positions. The Thomson Company has purchased such traditional legal publishing companies as Lawyer's Co-operative, Bancroft-Whitney, Callaghan, and Warren, Gorhanı \& Lamont. In addition, Reed Elsevier has acquired LEXIS, now a central player in the legal information environment after 20 years of developinent. ${ }^{5}$

Furthermore, a variety of imterest groups are floating proposals that would change the basic nature of how legal information is provided and cited. 6 The Department of Justice, while puzzling over how to handle its

1. There is a growing literature in the law on the impact that the categorization of information has upon the ability of lawyers and judges to function. See Richard Delgado \& Jean Stefancic, Why Do We Tell the Same Stories?: Law Reform, Critical Librarianship, and the Triple Helix Dilemma, 42 StaN. L. Rev. 207 (1989); Steven L. Winter, Transcendental Nonsense, Metaphoric Reasoning, and the Cognitive Stakes for Law, 137 U. PA. L. Rev. 1105, 1148-56 (1989). For wonderful background on the issue, see M. Ethan KatSh, LAw In A Digrtal Wordd (1995).

2. See, e.g., CaL. Law., Jan. 1995 passim.

3. See, e.g., Timothy L. O'Brien, Computer-Aided Legal Research Subject of Probe, WALL ST. J., Oct. 3, 1994, at B5; Greg Steinmetz \& Raju Narisetti, Reed Elsevier Wins Bidding for Lexis/Nexis: Publishing Concern to Pay a Total of \$1.5 Billion for Mead On-Line Unit, WALL ST. J., Oct. 5, 1994, at A3.

4. Morning Edition: Access to Electronic Legal Cases Hits a Snag (NPR radio broadcast, Jan. 26, 1995).

5. The price is reported as $\$ 1.5$ billion. Steinmetz \& Narisetti, supra note 3, at $\mathbf{A 3}$.

6. See, e.g., American Ass'n of Law Libraries, AALL Task Force on Citation Formats Report (Mar. 1, 1995) [hereinafter AALL Task Force Report]. This Report urges adoption of a new formatneutral citation form. Id. In 66-69. While not adopted by the American Association of Law Libraries ("AALL") as of this date, the Task Force Report is being widely disseminated. See also Robert L. Oakley, Letter to the Attorney General, AM. Ass'N L. LIBR. NewsL. (Chicago, Ill.), Nov. 1994, at 130, 132; Letter from James Love, Director, Taxpayer Assets Project, to Legal Publishers (Oct. 6, I994) (on file with author). 
own information systems, is also raising fundamental questions about legal information. ${ }^{7}$ Finally, everyone seems to have a complaint about the most traditional of legal publishers, the West Publishing Company.

All of these developments are set against the background of a clearly articulated national agenda of building an information superhigliway. ${ }^{8}$ The popular news media love the information superhighway and the concept of free information in every schoolroom. ${ }^{9}$ The burgeoning culture of electronic information centering on the Internet raises new possibilities for the dissemination of legal information and new questions about how this culture will relate to the users of information.

These changes may seriously affect the nature and distribution of legal information. The stakes are high. How reliable and accessible will infornuation be in the next generation? What is the most equitable method for distributing information to the public? In a free society these are fundamental questions. Far too often we fail to recognize the value of information we already have. The bells and whistles of newly emerging technology can make one forget the bread and butter. As Otis Redding sang, "You don't miss your water 'til the well runs dry. "10

A number of individuals and interest groups currently propose two potential reforms to the existing legal information edifice. The first proposal, focusing on the public's right to information, is that the government make legal information available to the public at no or very low cost. ${ }^{11}$ The goal is to bypass the existing for-profit publishers who currently provide such information. Most likely, this proposal would require that the government publish legal information im an electronic format. The second proposal is to change the citation system that lawyers use to identify those cases to which they refer in their arguments. ${ }^{12}$ Courts often require citation to certain printed sets of cases, effectively compelling lawyers to purchase

7. U.S. Dep't of Justice, Justice Department Seeks Improved Public Access to Court Rulings (Sept. 2, 1994) (press release on file with author) [hereinafter Justice Department Press Release]. The Justice Department also recently initiated a preliminary antitust investigation into the on-line legal research services industry. See O'Brien, supra note 3, at B5.

8. See Office of Science and Technology Policy, National Research and Education Network Program: A Report to Congress 1 (1992) (noting that Congress has mandated a program to "establish a gigabit communications infrastructure that will dramatically enhance the ability to collaborate among members of the research and education community").

9. Sce, e.g., Philip Elmer-DeWitt, Welcome to Cyberspace, TMm, Spring 1995, at 4; We're Heading Down the Information Superhighway, USA TODAY, Sept. 1994, at 8.

10. Otis Redding, You Don't Miss Your Water, on Otis BLuE/Otis Redding Sings Sour (Atlantic Records 1965).

11. A good statement of the position can be found in the AALL's Government Relations Policy, revised October 1992, regarding the dissemination of government information. AMERICAN Ass'N OF Law LIBraries, AALL DRRECTORY AND HANDBOOK 1994-1995, at 713 (34th ed. 1994) ("Federal, state and local governments have a duty to disseminate government information to their citizens. Government information slould be available to the public at no or low cost ....").

12. A representative example is a public domain system of citation, which is discussed in the AALL Task Force Report, supra note 6. 
case reporters produced by a specific publisher. By changing to citation formats that do not refer to the products of specific vendors, indeed that do not require a paper format, it is hoped that other case reporter publishers, taking advantage of new technologies, will enter the market. The desire to erode the West Publishing System's dominance in the legal information industry may have largely motivated both of these proposals, although both the Reed (LEXIS) and Thomson companies may be the next targets. ${ }^{13}$

In this essay I will comment on these two proposals. Both should be approached with caution, for they threaten to imterfere seriously with the normal operation of the legal information market. This market, which so far has produced an unparallcled system of comprehensive legal information that is accessible to users of all sophistication levels, must be allowed to continue unimpeded. I will also address the pervasive animosity towards the West Publishing Company, viewed by many as sort of a dark force in legal information, which in part has motivated these proposals.

The purpose of this essay is to examine the questions that undergird each proposal. What is most important is that we, as a society, understand the serious implications of the changes we make to the legal information system. Those who practice, teach, and write about law need to recognize the fundamental nature of the public imterest in the legal system.

\section{The Premise: The United States Possesses the World's Best Legal Information System}

Informing the discussion that follows is an absolutely crucial premise: that the Umited States has the world's best legal information systein. As of 1995 , it is possible for any literate, Enghsh-speaking person to walk into a local library, perhaps one that specializes in law, but perhaps not, and find federal and state court cases, statutes, and administrative law. ${ }^{14}$ Through

13. LEXIS and West joined forces to support an amendment to the 1995 Paperwork Reduction Act, H.R. $830 \S 3518(\mathrm{f})$, prohibiting the government from appropriating "value-added" information. See James Love, HR 830, Paperwork Reduction Act (Feb. 10, 1995) (Internet posting, available on the Internet at law-lib ucdavis.edu). Although this amendment failed in committce, the alliance is a harbinger. See H.R. Rep. No. 37, 104th Cong., 1st Sess. at *3 (LEXIS, Legis library, Cmtrpt file). These established publishers, long enemies, likely will be thrown together. A group called the American Association of Legal Publishers, consisting of smaller legal publishers, has targeted West in what it calls a "bitter struggle" against West's "de facto monopoly." American Ass'n of Legal Publishers, Supreme Court Scliedules Private Briefing for West Publishing Company Invitees (Feb. 9, 1995) (press release on file with author).

14. Some who have viewed drafts of this essay dispute this statement. Carol Billings, AALL president, explicitly challenges it. "If the numbers of AALL-affiliated libraries are an accurate indication, two-thirds of the states have-outside their major cities-vast wastelands of inadequate aceessibility to legal information." Carol D. Billings, Viewpoints: Advantages, LeGAL INFo. ALERT, Jan. 1995, at 6. I disagree. There are certainly some areas that rcmain unserved, but they are limited. An "AALL-affiliated" library is one that is staffed by a full-time law librarian who belongs to the national association. It excludes libraries staffed by those who do not belong to the AALL evcn if they do belong to any of the two dozen regional law library associations. It also excludes public and college libraries 
the use of a local, county, or municipal law library, or a public library, that same citizen can gain access to state statutory and administrative law, as well as a variety of secondary sources on the law. The system has limitations, but they do not contradict the premise. The citizens of no other nation on earth have such ready access to the legal information that is iniportant to them.

The heart of this system is the private sector. Private entrepreneurs, and not the government, have funded the production and formatting of legal information. Their contributions include the West National Reporter System, the American Digest System, the Total Client Service Library, Shepard's Citations, and a plethora of regional and state publications. The story of each tool and publication is a saga in itself, ${ }^{15}$ but in the end the collective efforts of private-sector companies have produced a paper-based system of information that tracks almost every piece of relevant legal data, organizes it, and brings it into the public arena.

The public sector also plays an important role in the legal infornation mix. The Depository Library Systen, which provides an extensive coverage of federal administrative and statutory materials, ensures that every Depository Library has a strong collection of legal materials. ${ }^{16}$ Such libraries niay not be as quick or as easy to use as one might wish, but they are a powerful back-up to the private providers of legal information. In addition, some states have a tradition of producing high-quality legal information. ${ }^{17}$

Nevertheless, in the area of cases and case-related materials, it is primarily the private sector that has responded to the need for comprehensive legal infornation. The story of how legal publishers have liberated legal information users, once subjected to disorganized government publications, has been told many times. ${ }^{18}$ None of this is to say that the paper system is perfect; I take second place to no one in iny criticisms of it over the years. ${ }^{19}$ The point is that the systein functions, and functions better than any other in existence. One of the doctoral students whom I supervise is from China,

that have basic law collections. For use of a collection on your own, see generally STEPHEN ELIAS \& Susan Levinkind, Legal Research: How to Find and Understand the Law (3d ed. 1992).

15. See, e.g., George S. Grossman, Legal Research: Historicai foundations of the Electronic Age (1994); Erwin C. Surrency, A History of American Law Publishing (1990); Patti Ogden, "Mastering the Lawless Science of Our Law": A Story of Legal Citation Indexes, 85 LAw LIBR. J. 1 (1993).

16. The Depository Library System is a program under which the federal government supplies certain government publications free of charge to designated major libraries for use by the general public. See generally Joe Morehead \& Mary Fetzer, InTroduction to United States GOVERNMENT INFORMATION SOURCES 47-77 (4th ed. 1992).

17. The state of Washington, for example, has long prided itself on producing legal publications that are as complete and timely as those of commercial publishers.

18. See Grossman, supra note 15; SurRency, supra note 15.

19. For critiques of the paper systems see Robert C. Berring, Collapse of the Structure of the Legal Research Universe: The Imperative of Digital Information, 69 WASH. L. REv. 9 (1994); Robert C. Berring, Full-Text Databases and Legal Research: Backing into the Future, 1 HiGH TECH. L.J. 27 (1986). 
and she always helps me keep perspective on this basic premise by poimting with wonder at how well we move around legal information in this country.

The healthy market in legal information has produced innovations im electronic research as well. Law leads all other fields in the distribution of digital information. LEXIS and WESTLAW, the most widely used full-text on-lime systems in the world, ${ }^{20}$ have added a new dimension to search capacity. First Boolean searching, and now relevancy-driven search engines like WESTLAW's WIN and LEXIS' FREESTYLE, have appeared. Electromic publishing of legal information has introduced the potential to reduce the delivery time of information. Even more importantly, these two mdependent private entities have expended enormous resources to provide training for a generation of law students. There is now a population of legal information consumers who are perfectly counfortable with using on-line systems and who thus can be led more easily to use other similar systems in the future. Any information vendor who can build a user interface that operates much like the one used to operate LEXIS and WESTLAW can count on an existing legion of acclimated users. Just as the proper research tools developed for legal information were ahead of their time, so too are the electromic products. Law leads the way in changing the culture of research.

The flowering of this new information culture has opened the door for other innovative digital systems as well. In the past few years an incredible number of compact disc-based ("CD ROM") systems have been introduced to the legal information market and are gaiming growing audiences. In California and New York, legal information seekers widely use compact discs produced by the Thomson Company. Indeed, New York and Califorma have designated these CD-ROM products as official reports. ${ }^{21}$ Law Office Information Systems ("LOIS"), a company that started producing compact discs of cases in Arkansas and has now expanded to other states, has also made a strong presence in legal publishing. There are other sinall publishers appearing daily. More and more legal inaterials are available directly on the Internet, where users can access and download primary

20. The educational programs for law students sponsored by each vendor provide training, support materials, and a free password that affords daily access to the database for each law student at each ABA-accredited school. This system has created an army of users of computerized legal information. An entire generation of law students have gone through this experience.

21. By statute, California and New York have official state reporters. CAL. Gov'T. CODB $\S \S 68900-68904$ (WeST 1987); N.Y. Jud. LAw $\$ \S 430-433$ (MCKINNEY 1983). Califomia does not print the California Reports and California Appellate Reports on state printing presses. It contracts with a commercial printer to actually produce the volumes. The Bancroft-Whitney Company always wins the contract. The contract, which was last put out to bid in 1991, specified that the new official report should appear in print and as an official compact disc. Thomson's purchase of Bancroft-Whitney has made Thomson the publisher of an official compact disc of Califomia decisions. Thomson combines this official compact disc with other dises of California statntes and Witkin's, a popular practice set with hypertext links between all sources. Thomson is also the offieial publisher in New York. 
source data. ${ }^{22}$ For example, Cornell Umiversity's Legal Information Institute, captained by former Cornell Law Dean Peter Martin and his associate, Thom Bruce, has created a public-access, worldwide site of legal information. In addition, electronic bulletin boards that contain primary sources, practice guides, and peer discussion are proliferating. Innovation is everywhere.

I certainly am not suggesting that the publishers that have produced this system have charitable motives. There is money to be inade in legal publishing, and the companies that enter the fray do so with profit in mind. One assumes that Reed Elsevier, in paying $\$ 1.5$ billion for LEXIS, ${ }^{23}$ is motivated by a desire to aid legal researchers only to the extent that this investment provides a sufficient financial return. The most important element of the future of legal information may be the jousting between Reed Elsevier (LEXIS, Michie, and Martindale-Hubbell), Thomson (Lawyer's Co-operative, Bancroft-Whitney, and Information Access) and West as they clasli over how best to create new tools and coinpete for profits. Nor should we discount the role of small companies such as LOIS in this competition.

This kind of corporate competition makes solne uneasy. ${ }^{24}$ But such "corporate wars" are nothing more than the normal operation of the market system on which the United States has relied for generations to satisfy its legal information needs. Competition for profits has produced quality. Anyone wanting a simple example of what happens when the inarket is not at work need only compare the United States Reports, the officially produced version of United States Supreme Court decisions, with privately published reporters covering the same cases. The United States Reports is compiled by a Court-appointed reporter and published by the Government Printing Office. It is a well-produced set of reports that provides readers with Supreme Court decisions one or two years after they have been handed down by the Court and long after they have been published in the private reporters. ${ }^{25}$ Whereas a government-subsidized system can live with that sort of egregious delay, private publishers responding to inarket demands and seeking profits cannot. Who would subscribe to sucli a set unless forced?

The real beauty of the changes now taking place in the legal information system is that the traditional paper-based system keeps those who are

22. James Milles, Internet Handbook for Law Librarians 28-29 (Roy M. Mersky, ed. 1993); Erik J. Weels, The Legal List: Law-Related Resources on the Internet and Elsewhere (version 5.0) (Aug. 17, 1991) available online ftp.midnight.com/pub/LegalList/legallist.txt.

23. See supra note 5 and accompanying text.

24. Librarians have long been uneasy when confronted with the marketing that is part of the private sector. See Patricia Glass Schuman, Librarians and Publishers: An Uneasy Dance, WrLsoN LIBR. BuLL., Dec. 1994, at 40 (noting that "[r] elations between the hibrary and publishing communities are often strained and sometimes nonexistent").

25. As of February 1, 1995, the Government Printing Office had issued advance sheets for 502 U.S. (1) covering October 7, 1991 to January 10, 1992 and the bound volume for 496 U.S. covering up to June, 1990-two and one-half and five years behind, respectively. 
not yet on the information superhighway in the picture, while the incredible array of digital products allows legal researchers to experiment with the outer edges of progress. These changes, in inany senses, have created the ideal situation. Given the safety net of the existing paper system, we can safely encourage all manner of innovation. Indeed, legal information consumers don't have to do anything other than consume. The market will sort out the winners.

\section{II}

\section{The AtTaCK on the Existing System}

Given the existence of a widely distributed, low-cost paper system that makes the law available to almost everyone, two competing full-text systems, and a plethora of innovative systems mibbling at the future, one would think any assessment of legal information would be largely optimistic. But increasingly this is not the case. For a series of separate but intertangled reasons, some individuals and groups are bent on bringing about major changes in the system. Their criticisms merit careful examination.

\section{Free Information for the Public}

One of the inost potent arguments against the current systein is that legal information is nothing more than the law itself, and that the law itself belongs to everyone. ${ }^{26}$ Accordingly, the law should be made available for no cost, or at least at very low cost, to all.

Depending on how "all" is defined, this logic suggests two sets of proposals. If "all" refers to each person, then the goal of providing free or lowcost legal information to all presumably means that the government should be the provider. Indeed, the Department of Justice is mulling just such a possibility. ${ }^{27}$ Furthermore, a number of groups have recently made it clear that they want the government to build a new legal information system. ${ }^{28}$ The Executive Board of the American Association of Law Libraries ("AALL") passed a resolution at its Noveinber, 1994 meeting calling for the developinent of sucl a system, one that would be "free" to all citizens. ${ }^{29}$ The Taxpayer Assets Project ("TAP"), a consumer group headed by James Love, has been at the vanguard of this novement. ${ }^{30}$ If, lowever, "all" is

26. It has been established since the 1834 decision in Wheaton $v$. Peters that the text of judicial opinions is not copyrightable. See Wheaton v. Peters, 33 U.S. (8 Pet.) 591, 668 (1834). This is the end of anything simple that can be said about this voluble area.

27. Justice Department Press Release, supra note 7.

28. See supra note 6 and accompanying text.

29. American Ass'n of Law Libraries, Resolution of the Executive Board of the Amcrican Association of Law Libraries (Nov. 6, 1994) (on file with author).

30. See James Love, Four Years of Struggles to Free the Law, Background Comments for Conference on Computers, Freedom and Privacy, 1995 (Mar. 31, 1995) (on file with author) (summarizing TAP's efforts to increase public access to legal information); Letter from James Love, Director, TAP, to Sen. Phil Gramm, Chair, Senate Appropriations Subcommittee on Commerce, Justice, 
read as meaning those who are only interested in redistributing legal information, then making such information available to all means granting potential publishers full access to the proprietary information of established legal publishers.

Both sets of proposals are motivated to a large extent by an unfair criticism of the West Publishing Company. Critics have attacked West for its role in distributing cases via the National Reporter System and for claimmg to own the final formulation of its product. ${ }^{31}$ West's critics seem to argue that West's product is a public good, and that West unfairly enjoys either a monopoly or an exclusive franchise in certain legal materials. According to this view, West exploits its access to this public commodity to profit at the public's expense. West does this by claiming a copyright both $\mathrm{m}$ its editorial enhancements to the cases and in the pagination scheme in its reporter volumes. Since West volumcs are the required citation in some courts, critics contend that West thus owns the law. ${ }^{32}$ To end this anticompetitive behavior, West's detractors urge either that the government take its rightful place as the primary publisher of legal information and distribute it for free or that other publishers be given access to West's proprietary information. Granting such access would then lead to substantially enhanced competition and lower costs to information users. Legislation has been introduced to accomplish this end, ${ }^{33}$ and various scholars have attacked West's intellectual property claims to existing West-edited case law.

This view is flawed because it conceives of the West system as the only possible system of legal information. It is true that the National Reporter System has become the backbone of American legal publishing. The National Reporter System is so much a part of the furniture of legal information that many users think of it as the only method of case publication. If such a premise is accepted, then West-like the owner of an artesian well or other natural resource-only has to package the product and it sells. If this analysis is correct, West makes a fortune merely doing what anyone could have done.

For years I have worked to disabuse my students of that notion. The National Reporter System is not obvious until it is there. It did not fall from the heavens; it is the product of a series of editorial and inarket decisions and a survivor of a highly competitive marketplace. ${ }^{34}$ John $\mathrm{B}$. West had an original way of doing things, much criticized at the time, but ulti-

State and Judiciary (Mar. 22, 1995) (on file with anthor) ("A democracy should not allow one firm, West Publishing, to 'own' and control access to the law.").

31. See Susan Hansen, Fending Off the Future, AM. LAw., Sept. 1994, at 74, 76; Gary Wolf, Who Owns the Law?, WiRed, May 1994, at 98, 98.

32. See Wolf, supra note 31 , at 98.

33. H.R. 4426, 102d Cong., 1st Sess. (1991).

34. SURRENCY, supra note 15 , at $49-52$. 
mately successful. ${ }^{35}$ John B. West first and most importantly obtained the cases. Then he published them quickly, accurately and comparatively cheaply, with no sifting. He organized them into regional reporters for state cases and into two, and later three, tiers of federal cases. Then he sorted the data through the American Digest System. The result was a comprehensive, organized system of information. It was far from perfect, ${ }^{36}$ but it provided relatively mexpensive distribution of legal case law.

The National Reporter System is hardly the only way to report and organize cases. The decision to produce cases jurisdictionally, with no separation of civil and criminal matters, for example, is neither intuitive nor obvious. One can grow so used to the design of the carpet that one can see no other possibilities. Indeed, parallel systems did flourish, and many were based on entirely different information algorithms such as loose leaf services, American Law Reports, and official reporters.

The development of LEXIS demonstrates that one can even construct a comprehensive reporting system in a completely different way, by putting the full text of each case into an on-line database and allowing each searcher to create her own custom database. LEXIS built an alternative universe of legal information. Many derided LEXIS during its first decade, but LEXIS met the test of the market and it survived. LEXIS is now accepted as a standard, rehable information source.

The Thomson Company may be working toward yet another type of comprehensive reporting method. With its growing family of state-based compact disc products that link state statutory compilations and secondary tools with hypertext links and with its special position as official reporter of decisions im New York and California, Thomson may be building an entirely new case reporting edifice. Nor should we forget that state and local governments have continued to be information providers. Official reports were well-established when West canie on the scene. In many cases they just didn't do a very good job. ${ }^{37}$ Thus, there are many ways to produce information; the National Reporter System is just one paper-based, relatively mexpensive way that succeeded. By no means does West have a strangleliold on the publication of case materials.

However flawed the current legal information system, a system of government publishing is even less appealing. Government printing has com-

35. For a contemporary articulation of the intellectual battle see $A$ Symposium of Law Publishers, 23 AM. L. Rev. 396 (1889), reprinted in Legal Reference Services Q., Winter 1981, at 73.

36. See supra note 19.

37. It is worth noting that 31 states still have official reporters of judicial decisions. Letter from Robert C. Berring, Law Librarian, U.C. Berkeley School of Law, to William J. Hughes, Chairman, House Judiciary Subcommittee on Intellectual Property and Judicial Administration (June 5, 1992) [hereinafter Berring Survey] (surveying court citation requirements) in Exclusion of Copyright Protection for Certain Legal Compilations: Hearing on H.R. 4426 Before the Subcomm. on Intellectual Property and Judicial Administration of the House Comm. on the Judiciary, 102d Cong., 2d Sess. 164, 169-72 (1992). 
piled a dismal record. Most librarians can only shake their heads with dismay when contemplating the actions of the Government Printing Office in recent years. ${ }^{38}$ Even when the government does do a good job-the Code of Federal Regulations ("CFR") is efficient and timely-it fails to provide the auxiliary aids like good indexes, finding tools, and easily used updating, which are critical to information users. Hence, even where the CFR is up-to-date, users still prefer loose leaf services or databases. In all likelihood, government legal information systeins will always be bareboned at best.

A separate difficulty arises from the ninubus of politics that inevitably surrounds government activity. The magnitude of the problem is illustrated by Vice President Gore's statement that U.S. post offices will house the computer terminals that he envisions will allow members of the public access to the information superhighway. ${ }^{39}$ Think about that for a inoinent. The Postal Service is known neither for its efficiency nor for its helpfulness. Why use it to house the information superhighway? The answer is that the Postal Service fears that growing use of e-niail will erode its function. It seeks a new role; it is lobbying for this one. Such a decision on national information policy might then be nuade based on political interplay. This demonstrates the problem of getting the government and politics involved in the distribution of information. Can anyone who has watched the Library of Congress or the Depository Library Program really believe that the federal government can provide quality information in a timely manner at a low cost? ${ }^{40}$ State governments are no better. Consider the success that the West National Reporter System has enjoyed. Even though 29 states liave official reporters, including those states most heavily populated by lawyers, the private versions continue to prosper. ${ }^{41}$

Proponents of government publishing also underestimate the barriers posed by the technology that would be needed. The issue of government publishing is inextricably linked to questions of new technology. Alınost all of the propounders of this position foresee some form of electronic information as the best ineans of distributing information to all consumers. ${ }^{42}$ Given the realities of the costs and limitations of print form, the only

38. See Dennis Baron, Getting a Read on Government Bungling, Crr. TRrB., Sept. 22, 1993, at 23 (stating that the Government Printing Office in Chicago doesn't receive government documents until months after they are issued).

39. Greg Pierce, Info Highway Leads to Pennsylvania Ave.: White House Open for Internet Tour, Wash. TMmes, Oct. 21, 1994, at A7.

40. See Jacqueline Trescott, Library of Congress To Cut Hours; Reading Rooms To Close on Sundays As Budget Tightens, WASH. Post, Feb. 3, 1994, at $\mathrm{Cl}$ (describing the Library of Congress as "short of cash but overloaded with work").

41. California, New York, lllinois and 28 other states require citation to an official reporter. See Berring Survey, supra note 37.

42. James Love, Viewpoints: Advantages, LeGAL INFO. AlerT, Jan. 1995, at 6. Internet postings on the LAW-LIB LISTSERV list (at Law-lib ucdavis.edu.), in particular those by John Lederer and James Love, discuss the advantages of electronic information. 
comprehensive alternatives to West that have appeared so far, or that are likely to appear, are in some electronic format. The utopian vision of an electronic information superhighway that provides every person in society easy access to all needed information undergirds this approach.

Any electronic format, however, would require extensive investment in new equipnent. For example, citing to a case available only in LEXIS means that everyone wishing to retrieve that case must have access to a LEXIS terminal. Over the years LEXIS has gained respect for its comprehensiveness and accuracy, but the preferred citation reniains to paper versions of information because these versions are so widely available. The use of the new conipact disc presents sinilar problenıs. Conipact disc players are falling in cost, but they require a personal coniputer to use. For library networking, conipact discs are still costly and cumbersonie. Perhaps someday everyone will have access to an on-line terminal and a conipact disc player, but this is not yet the case. But today alnost everyone can still get to a law library. For all of the limitations of printed information, it is cheap and easy to use. Thus the ability to locate and retrieve the printed sources for a reliable, verifiable citation reniains inportant.

I also worry that those who propose a government-operated legal information system, built on the foundation of digital technology, underestimate the cost and challenge involved. Sone think that one only need dunip the opinions of the court in raw form onto an electronic bulletin board to solve the information puzzle. Such raw data would do alniost no one any good. Only an expert could niamipulate it, and there would be huge problenıs of namimtenance, reliability, and security.

Furthermore, initiatives to enhance the public's electronic access to legal information involve technology that is as yet unfamiliar to the general public. Although the media's fascination with the information superhighway inay have momentarily deluded us, most folks are not ready for fulltext on-line legal information. ${ }^{43}$ Perhaps lawyers, or at least niost younger lawyers, are ready, but the public is not. The average patron in the law library of the Umiversity of California at Berkeley, which is state-supported and open to the public, cannot use the Internet. Even the extremely bright population of law students that inhabit the library's reading roonis needs the friendly software of WESTLAW and LEXIS to use on-line information. It is a hardy handful who truly can FTP and gopher their way across the Internet. ${ }^{44}$

43. In the spring of 1995,1 co-taught Advanced Legal Research to second- and third-year law students at Boalt Hall. An informal survey of the 150 students showed that only half had e-mail accounts, the most basic form of interaetive network activity. This sample of students at an elite institution is instruetive.

44. FTP, or "file transfer protocol," enables one to transfer a file from any Internet-connected computer to any other. MrLes, supra note 22, at 31. Gopher is a menu-based, hierarchical system for retrieving networked information regardless of where the information is stored. Id. at 37 . 
Any publicly developed system will lack bells and whistles and ultimately will serve only the technologically sophisticated user. The trend in the information industry is to produce products for end-users that offer easy, point-and-click interfaces. I was struck by this fact when attending the On-Line Conference in San Francisco in October 1994. This conference is attended by information vendors and is a showcase for new products. Most of the displayed new products focused on software interfaces that made searching autoinatic and simple. There are two important inplications of this trend. First, the users for wliom these systeins were designed-scientists and executives, for example-still need lielp searching. The information industry does not consider such users truly to be sophisticated. If educated segments of society still need menu-driven systems, how can the general public be expected to use the much more difficult Internet interfaces? Second, these easy-to-use systems, developed by the private sector, are expensive. The prices are not in the budgetary range of the general public or the public library. Thus one still has to have either significant skill or significant resources to navigate the information superhighway successfully.

The low-technology folks need the paper information systern of the National Reporter System if they are to get the information that they need. An on-line or compact disc-based system will not work for the patrons of the law library at U.C. Berkeley. With their budgets in retreat, most libraries lack the resources to train patrons and provide needed equipinent. ${ }^{45}$ Forcing a inajor switch to electronic information may achieve the very opposite of public access. If falsely imposed forces render the National Reporter Systein obsolete or erode its subscription base so deeply that the price rises inordinately, what becomes of the pro se patron in the public library?

Finally, there are two very real political problems here. First, any government effort to distribute free or low-cost legal information will benefit lawyers inore than anyone else. By far, the greatest use of legal information is made by lawyers in various guises, mostly to make money. If the government does expend significant resources to create an entirely new legal database, the greatest beneficiaries will be the for-profit legal community. Law firms will have the expertise necessary to inanipulate inost effectively the kind of raw data that a government system is likely to provide. It is hard to believe that suclı a system will not end up best serving the interests of the practicing bar. One would have to be incredibly naive to think that sucli a prograin will end up really being designed for the average citizen. Subsidizing the practice of law is hardly an attractive goal for public spend$\mathrm{mg}$ at this point in time.

45. See Michael R. Gabriel, Assessing the Adequacy of Academic Library Budgets, 1960-1990, TeCHNICALITIES, Oct. 1993, at 2 (describing financial difficulties experienced by research libraries in trying to meet demand for materials). 
A second potential political problem revolves around issues of charging the user access to legal information. There is increasing pressure on all government agencies to produce an income stream. Who is to say that a federally run system, once in place, will not start charging those who wish to use it substantial fees? ${ }^{46}$

If government publishing is not the answer to the goal of free access, making the proprietary information of a publisher like West freely available to competitors is even less so. Proponents of this view contend that this method of encouraging new entrants into the market will result in lower cost legal information. Conflating this kind of claim with a call for public access is simply misleading. West, Thomson, and Reed are not public entities. It is patently unfair to allow access to their proprietary information by rival publishers who have the opportunity to undergo the expensive and time-consuming process of getting original opinions from the courts, but who would obviously find it much simpler to use information that has already been compiled, edited, and published. Anyone who wishes to publish these cases can get their own data and start over, much as LEXIS and Barclays did. LEXIS had to establisli relations with each court to get the data. It did so. Barclays, a small San Francisco Bay Area company, collected data in electronic form from the courts and manipulated it. $^{47}$ Each built their own system. When private concerns battle, the government's role is to maintain a level playing field so that competition stays fair.

New information systems are coming. West itself, and many other companies, are laboring on that issue right now. The imperative to use the tools technology provides to construct a new style of information system is clear. The sticky part comes with the concept that the government should build the new system. Gathering the data, checking it for accuracy, and providing it in database form is both expensive and difficult. ${ }^{48} \mathrm{I}$ simply have no faith in the federal government's ability to do it well. Nor does this

46. The Judicial Conference of the United States recently voted to "reduce the \$1 per minute fee for users to 75 cents per minute" because of the increase in the number of courts offering electronic access to court data. Administrative Office of the U.S. Courts, Judicial Confcrence Reccives Long Range Plan 2 (Mar. 14, 1995) (press release on file with author). This is an odd way of saying that thosc circuits that had been giving free access to their electronic information now have to charge for its use$\$ 45$ an hour. There will be a fight over this, but it shows the increasing push for all elements of government to charge user fees that generate income.

47. In February, 1995, Bancroft-Whitney, a division of Thomson Legal Publishing, Inc., purchased Barclays Law Publishers. Monica Bay, Barclays Law Publishers Sold to Bancroft-Whitney, THE RECOPDER, Feb. 21, 1995 at 6.

48. In a LAW-LIB posting of October 10, 1994, Alan Sugarman (a produccr of legal information CD-ROMs) makes light of the editorial input of case publishers. Alan Sugarman, LAW-LIB posting (Oct. 10, 1994) (on file with author). He posits a case where the date reads 2094 as an example of a court error corrected by West's editors. 1 completely disagree. Over my 20 years as a law librarian 1 have seen numerous examples of shoddy reporting. It takes hard work, skill, and incentive (profit) to produce a high-quality product. Nor do 1 think that quality control will be any easicr with electronie systems. 
age of state and federal budget cutbacks ${ }^{49}$ seem to be the correct moment in history to ask the American taxpayer to fund the substantial costs of developing such a system.

\section{Changing the World Through Citation}

A second and closely related proposal for changing the legal information systein concerns citation, an issue of great importance to legal workers. Clear, reliable citations allow the researclier to find from where cited information came, and to go check upon it. Citation systems are especially important in the United States given the obsession with precedent in American common law. ${ }^{50}$ The Uniform System of Citation ${ }^{51}$ lias assumed such significance in law that, for some, proper citation form is almost a fetish. What greater glee than that of the law review editor initiating new members in the art of bluebooking?

Citation systems are also important because courts can affect what kinds of legal information systems are commercially viable by requiring that a specific citation system be used. For example, the United States Supreme Court traditionally requires citation to tlie official reporter, ${ }^{52}$ and state courts liave long required citation to an official reporter where there is one. $^{53}$ These requirements apply even if the official reporter is slow and not very useful. Once the official reporter appears, being authoritative, it must be consulted. In such situations, lawyers are forced to buy the official report when it becomes available. They may still use a commercial variant to retrieve information for their actual use, but the power of tlie court forces them to buy the official product. In this way, the political power of the courts or legislature, if it is legislation that creates the official report, can confer authority even on poor products.

Critics of the current citation regime argue that in situations where a jurisdiction lacks an official reporter and the courts require citation to West reporters, the courts liave exercised the citation power to give the West Publishing Company an unfair advantage over its competitors. ${ }^{54}$ Of course,

49. See Karen Foerstel, Heads of GAO, Other Support Agencies Defend Operations Against Budget Cuts, Roll CALL, June 14, 1993, at 12.

50. A frequently cited article on citation is Paul Axel-Lute, Legal Citation Form: Theory and Practice, 75 LAw LIBR. J. 148 (1982).

51. The Blueboox: A Uniform System of Crtation (15th ed. 1991).

52. Robert L. Sten et al., Supreme Court Practice $\S 13.6$, at 540 (7th ed. 1993) (stating that "Supreme Court decisions should be cited to the official United States Reports").

53. See e.g., CaL. R. Cт. 313(e); CAL Style Manual (3d ed. 1986) \& 68 (stating that litigants in Califomia courts should cite to the official state reporter).

54. For good background on the citation controversy, see Cary Griffith, A Vendor/Media Neutral System of Citation?, Information Today, Oct. 1994, at 16; Christopher G. Wren \& Jill Robinson Wren, Letting a Thousand Citation Systems Bloom, NETwORK 2D, Fall 1994, at 1. The January 1995 issue of Legal Information Alert contains a chronology of the citation controversy and statements framing both sides. For a good statement of the case for change, see Technology Resource Committee of the State Bar of Wisconsin, Proposed Citation System for Wisconsin, Report to the Board of Governors (June 22, 1994) (on file with author). 
in inany such jurisdictions West, through its National Reporter System, has produced the only systematic set of judicial decisions $m$ a paper format. In West Publishing Co. v. Mead Data Central, Inc., the Eighth Circuit upheld the full extent of West's copyright in the internal pagination of its reporters. ${ }^{55}$ West claims no interest in the citation to the first page of a decision. However, unauthorized copying and republication of the full internal pagination, the court ruled, constitute infringement. ${ }^{56}$ In those jurisdictions in whicll citation to West reporters and their page numbers is required, competing publisliers claim to be prevented froin entering the inarket. ${ }^{57}$

In an attempt to remedy this perceived inequity, some have proposed that citation requirements be changed to elimmate any favoritism towards West reporters. Louisiana, Wisconsin, and Colorado, for example, have considered creating new format- and vendor-neutral citation systems. ${ }^{58}$ Though there are variations, the basic idea is to provide eacli case witl a unique alplianumeric identifier and to number the paragraphs in the text of the case. ${ }^{59}$ The lope is that sucli a system will free researchers froin the need to find the information in any partieular format; if the citation is tied to paragraphs ratler than page numbers, it is forınat-neutral.

The problem with current citation systems is overstated. In reality, courts are rather flexible in accepting new citation formats when the inarket dictates. Some years ago Kathleen Vanden Heuvel and I surveyed courts to find what would happen if a lawyer wanted to cite a case available only on

There has also been a torrid debate raging on the LAW-LIB bulletin board-a LISTSERV read by law librarians throughout the United States-during the last half of 1994. See Anthony Aarons, Love Letters: A West Public Relations Professional Dukes It Out with a Consumers Advocate in a Cyberspace Debate, CAL. L. Bus., Jan. 9, 1995, at 12.

55. West Publishing Co. v. Mead Data Cent., Inc., 616 F. Supp. 1571, 1579 (D. Minn. 1985) (granting preliminary injunction enjoining Mead from introducing "star pagination" to West reporters on LEXIS and denying Mead's motion to dismiss for failure to state a claim), aff'd, 799 F.2d 1219 (8th Cir. 1986), cert denied, 479 U.S. 1070 (1987).

Following these decisions, West and Mead entered into a license agreement permitting Mead to provide star pagination on LEXIS to West reporters. L. Ray Patterson \& Craig Joyce, Monopolizing the Law: The Scope of Copyright Protection for Law Reports and Statutory Compilations, 36 UCLA L. REv. 719, 720 n.1, 722 n.6 (1989).

56. West Publishing, 616 F. Supp. at 1579-80. Some commentators feel quite strongly that the case was decided incorrectly. See, e.g., Patterson \& Joyce, supra note 55, at 728.

57. The question here is part of a large and complex family of issues that electronic information, and the ease of electronic publication, will force on the courts. Given the fact that the courts have not yet parsed out the law concerning the use of photocopiers, we may wait a long time for legislative help on this matter. See American Geophysical Union v. Texaco Inc., 802 F. Supp. 1, 30 (S.D.N.Y. 1992) ("Generally speaking, the decisions of the Supreme Court on fair use have not formulated a clear framework or standard governing future cases."), aff'd, 37 F.3d 881 (2d Cir. 1994).

58. See AALL Task Foree Report, supra note 6, $\{$ 45-65 (discussing proposed or adopted new citation forms in various jurisdictions); see also Marcia J. Koslov, What is the Citation Proposal?, WISc. LAW., Feb. 1995, at 10.

59. Lynn Foster, Electronic Publication and Legal Citation Form: A Discussion and Proposal (Oct. 4,1994 ) (draft) (on file with the AALL Task Force on Citation Formats). For a full exploration of this issue and a useful bibhography, see Legal INFO. ALERT, Jan. 1995, at 10 and passim. 
LEXIS. ${ }^{60}$ We expected to find real barriers-that courts would resist allowing material cited only on-line to become part of the information mix. We were surprised to find, however, that most courts were quite accommodating, requiring only that the citing party provide a copy of the printout to all parties. Citation rules were not nearly so rigid as we had anticipated. In a second survey done in 1992 at the request of a House Subcommittee, I cliecked state and federal courts to see if they required citation to a particular source. This study produced the same result. ${ }^{61}$ In other words, a court might require one to cite to an official source where one was available, but also might be forgiving if the information was in a variant format. An economy of information seemed to operate here. Indeed the trend has long been for official information sources to wither away, stepping aside to allow the commercial products to carry on. The commercial sources simply have done a better job.

Changing to a format-neutral citation scheme may well prove beneficial if tried as an alternative, but only if it does not preclude existing citation systems. Problems arise if the new system not only proposes a vendorneutral citation system, but also forbids parallel citations or use of any citation system but the new neutral one. State courts would no longer be so accommodating in accepting alternative citation forms. Under the Wisconsm proposal, for instance, the only authoritative citation would be to docket and paragraph numbers. Such a rigid, vendor-neutral requirement would make the world of citation far more restrictive than it has ever been in the past.

Under no circumstances should citation requirements be changed in a way that would interfere with the natural evolution of legal information in the marketplace. To understand the depth of my reservations, one must return to the original premise that the Umited States has the best legal information system in the world, and that this system was produced by the market. Citation systeins respond to the same market forces. Users of information seek reliable and inexpensive sources of that information. When one cites something, one is trying to provide an accurate, readily findable clue as to where the reader can go look at the source for herself. ${ }^{62}$ Consequently, citation systems build themselves around reliable, widely distributed information.

For example, because commercial products proved so much quicker, cheaper and more reliable than official reports, various schemes such as star paging arose to allow one using a nonofficial tool to be able to convert

60. Survey results on file with author.

61. An informal survey of court rules show that 15 of 101 federal district and circuit courts required citation to West publications, as did seven of the states without official reporters; however, these citation rules may be ficxible in practice. Berring Survey, supra note 37, at 164-65.

62. Paul Axel-Lute's article, Legal Citation Form: Theory and Practice, supra note 50, has become the touchstone for citation discussions. 
citations within it into the required citation. Similarly, parallel citation emerged in recognition of the fact that the most likely set available to the user would be the commercially produced set. The court's political power thus can create and enforce a citation system, but good information systems still find a way to survive and embed themselves in the information mix. Currently, people want to cite to West's page numbers in certain jurisdictions because those materials are dependable and readily available. If paragraph citation is sensible and useful, let the market anoint it. But moving to make it mandatory substitutes political acumen for market judgment and is not a trade-off that inspires me with confidence.

Another problem with changing citation systems is that a formatneutral system makes it much more difficult to evaluate the reliability of information sources. The main purpose of citation is to direct the reader to a source where the accuracy of the cited information can be checked. In a system of politically enforced format-neutral citations, lawyers would be precluded from citing to the actual volume or database where they read the cited information. They could not disclose where imformation could be verified beyond the alphanumeric and paragraph number. It would be impossible to discover where the citing person really saw his information.

This anonymity would present no problem if one could rely on every vendor presenting the text reliably. Unfortunately, all reporters are not created equal, and it is very likely that one will find variant texts between competing products. Experienced researchers know how fragile quality control is. Anyone who thinks this is not a significant problem, especially where various entities will be beginning a new product, did not experience the agomies of the early LEXIS, or for that matter the WESTLAW, OCLC, or MELVYL databases. Each of these systems began with compromised data and had to work out methods for quality control and verification. The "bugs" commonly found im new software products are related phenomena. Having visited the West Publishing Company, the LEXIS facility, and Bancroft-Whitney, I have seen the tremendous amount of editorial preparation that goes into the production of an accurate information service. Format-neutral citations rob the final product of real accountability and remove the ability to really verify that one is looking at the same data as that cited.

Furthermore, if the citation system for cases were to change, the lawyers and legal workers who use it would have to be retrained. The challenge of re-education would be enormous. Worse, it would be a nightnare if different states used different systems, a distinct possibility considering that the Colorado, Louisiana, and Wisconsin experiments are all different. But even if a new standard form is agreed upon, someone would have to retrain each legal worker. This may be a boon to continuing legal education providers, but it will make everyone else's life more difficult. The need for 
massive retraining may be the one thing on earth that could make the current system look good.

All of the concerns I have just raised also counsel against imposing changes to the citation system governing federal cases. Conventionally, lower federal cases are cited to the Federal Reporter and Federal Supplement published by West. ${ }^{63}$ Some have urged that the federal courts adopt a format neutral citation policy like that in the states discussed above, allowing citation to other sources and freemg researchers from reliance on the West system. ${ }^{64}$

However, the market should dictate any changes to the federal citation system. Citation to West reporters is currently the norm because the market lias decided this. The practice originated during the time when one had to use the West reporters to get the text of lower federal court decisions. Today there are alternatives to the West reporters. LEXIS and WESTLAW provide competition, eacl comprehensively reporting all the decisions found in the West books, and more. Other publishers like Barclays now inake large segments of the lower federal court cases available in print and on-line, ${ }^{65}$ and the variety of compact disc publications is little short of stunning. For the technologically adept, some circuits post digital versions of opmions on bulletin boards. Still, the West-based citation system survives because the West paper-based system is reliable and inexpensive. A citation system should provide a road map to existing information systems. To create the citation system first, in the hopes that a new information system will grow, is to put the cart before the horse. If the time comes to abandon citation to the Federal Reporter, let the users choose when to do so. If the need arises for more federal case reporters, or federal case law in a different format, let the market decide what is needed and reward it with patronage. When good information systems emerge, in whatever format they may take, citation systems will follow.

These marketplace notions equally apply to proposals that the federal courts publish their own cases. The fact that there is no official case report for the decisions of the Federal Courts of Appeals and the Federal District Courts has long struck some commentators as odd. ${ }^{66}$ One could say that the failure of the federal government to systematically publish its lower court opinions proves that government is not a gifted publisher of such informa-

63. The Bluebook: A Uniform System of Citation, supra note 51, at 166.

64. See, e.g, Love, supra note 42 , at 6.

65. Barclays Law Publishing maintains an on-line database of all United States Supreme Court opinions and all federal Court of Appeals opinions. They can deliver the opinions to the user in paper format or via e-mail upon demand. One can also obtain all such cases by subject. This is just one example of alternative reporting systems.

66. Of course, nineteen states have no official reporter either. Berring Survey, supra note 37, at 169-72. But given both the importance of the federal judicial opinions and the proclivity of the federal government to publish information, the absence of official reporters for lower federal courts is a bit surprising. 
tion. On the other hand, one might say that the private sector so satisfies the courts that the courts see no need for government-published federal case reporters. In any case, given the current excellent system of federal case distribution, it probably has been a wise choice. The federal courts are famous for their fierce mdependence, not for their skill as information distributors. So why risk it?

Finally, if the world continues to move to electromic information, the page number controversy will be old news indeed. Carol Billimgs, AALL president, has appointed a task force chaired by Professor Lynn Foster of the University of Arkansas Law School to examine issues surrounding citation. The Task Force has issued its report, which will be considered at the July 1995 AALL meeting. ${ }^{67}$ This kind of action by library professionals may help plan and smooth out the transition from paper-based to electromic systems. For now, though, in the real world of 1995 populated by real users, page numbers should always appear in a parallel cite for the use of the low-end users. The market will accept new citation formats when it is ready.

\section{West as the Evil Empire}

The West Publishing Company has long occupied a central position in legal publishing. It may seem absurd or trivial to even discuss this issue, but it infects each of the others. The vitriol directed towards West is real. ${ }^{68}$

West should not be faulted for either seeking profit or for fighting to protect what it believes to be its property. West is a private enterprise that produces information for a profit. As such, it is entirely rational for West to seek profits and to defend the very property by which it generates mucli of those profits. West has long fought hard for its market share, and its owners and employees care a great deal about their product.

In the end, however, the final measure for judging a legal publisher should not be its corporate citizenship, but rather the quality of its products. By that measure, West is to be commended. West's printed products are of high quality. If the premise regarding the superiority of legal information distribution system in the Umited States is correct, West deserves credit, not criticism, for its contributions to this system. Admittedly, West has made

67. AALL Task Force Report, supra note 6.

68. For a discussion of attacks on West by competitors and consumer advocates, see Hansen, supra note 31, at 75; Leiter, supra, note 12, at 1; Wolf, supra note 31, at 98 . Some of the discussion has been quite heated, if spectacularly uninformed. On February 13, 1995, James Love posted on the Intemet a memorandum written by Mike Radway, Legislative Direetor for Rep. Paul Kanjorski (D-Pa.). James Love, LAW-LIB posting (Feb. 13, 1995) (on file with author). In his second paragraph, Mr. Radway states, "The West Publishing Company, a Minnesota-based publisher of expensive legal books is attempting to maintain and expand its virtual monopoly on the U.S. Code and other important legal works." Given that the U.S. Code is available in various formats, including both a federally produced form available in every Depository Library and in the form of a competing, privately produced compilation (United States Code Service), West docs not hold a very credible monopoly. 
mistakes over the years, and can sometimes be maddening and even foolish. But in the end, the West Pubhishing Company has served a useful function.

It is also unfair to suggest that West has suppressed the competitive balance in the legal information market. West simply does not block others from entering legal publishing. For instance, there has been a veritable Oklahoma land rush into legal publishing in the past few years. It is a fecund time in this business. The government is the only entity that has not been a major player in legal publishing, and I have already expressed my relief at that. If West is fencing folks out, it is doing a very poor job.

There is also some irony in complaints about West's size and market impact. West is inuch smaller than the two other major players in legal information today, Reed Elsevier and the Thomson Company; it is also inuch smaller than the government. Reed owns LEXIS and other legal information sources and Thomson owns law book publishers, compact disc inakers, and indexing services and actually serves as the official reporter in the two largest states, New York and California. In this company West is the smallest fry. Moreover, unlike every other major law pubhsher, West remains an employee-owned close corporation solely devoted to law and textbook publishing.

As new systems develop, West will continue to face some deep pockets. It seems more logical for West's detractors, many of whom claim to have a concern with low-end users, to be rooting for the continued survival of the National Reporter System in its current low-tech form.

\section{CONCLUSION}

If one accepts the premise that the existing legal information system in the United States is the best in the world, then this essay's title becomes understandable. We must take care to make wise choices as we move into a new era. This may mean watching multiple systems develop and letting the users decide which is best. It may mean easing legal information into a completely electronic environment. What it should not mean is abandoning the current system and prejudicing the ability of low-tech users to find legal inforination by either destroying the National Reporter System or compelling it to become prohibitively costly. It should not mean turning over a system that works quite well to the good offices of the government in any of its manifestations. It should not mean dictating the change by mandating new citation systems. The current systein works. The market will let us know when a new one is ready. Experiments are welcoine and healthy as long as they do not prematurely dismantle the existing system. It would be tragic if those who advocate a wider distribution of information brought about an end to the best legal information system in the world. 
